\title{
INTERNATIONAL JOURNAL OF

\section{Interfaith Interaction Framework in Comparative Religion Course at the Department of Usuluddin}

\section{Tuan Syarifah Nursyaza Aina Tuan Mohd Zawawi, Aman Daima Md. Zain, Mohd Hasrul Shuhari, Mohd Safri Ali, Rahimah Embong, Hanif Md Lateh@Junid, Wan Mohd Fazrul Azdi Wan Razali}

To Link this Article: http://dx.doi.org/10.6007/IJARBSS/v9-i11/6587

DOI: 10.6007/IJARBSS/v9-i11/6587

Received: 10 October 2019, Revised: 30 October 2019, Accepted: 03 November 2019

Published Online: 13 November 2019

In-Text Citation: (Zawawi et al, 2019)

To Cite this Article: Zawawi, T. S. N. A. T. M., Md. Zain, A. D., Shuhari, M. H., Ali, M. S., Embong, R., Junid, H. M. L@., Razali, W. M. F. A. W. (2019). Interfaith Interaction Framework in Comparative Religion Course at the Department of Usuluddin . International Journal of Academic Research in Business and Social Sciences, 9(11), 652-663.

Copyright: (C) 2019 The Author(s)

Published by Human Resource Management Academic Research Society (www.hrmars.com)

This article is published under the Creative Commons Attribution (CC BY 4.0) license. Anyone may reproduce, distribute, translate and create derivative works of this article (for both commercial and non-commercial purposes), subject to full attribution to the original publication and authors. The full terms of this license may be seen at: http://creativecommons.org/licences/by/4.0/legalcode

Vol. 9, No. 11, 2019, Pg. 652 - 663

Full Terms \& Conditions of access and use can be found at http://hrmars.com/index.php/pages/detail/publication-ethics 


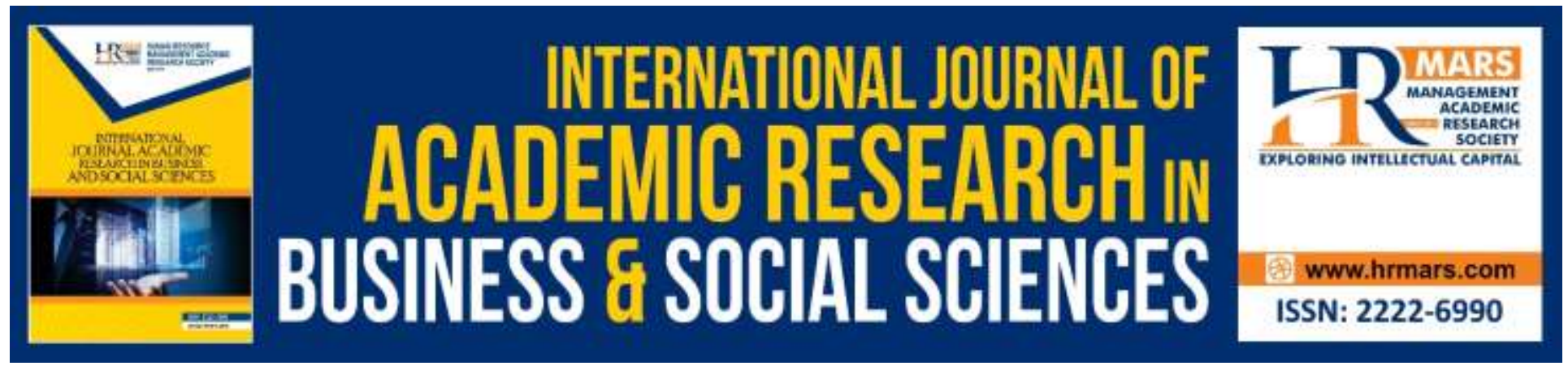

\title{
Interfaith Interaction Framework in Comparative Religion Course at the Department of Usuluddin
}

\author{
Tuan Syarifah Nursyaza Aina Tuan Mohd Zawawi, Aman Daima \\ Md. Zain, Mohd Hasrul Shuhari, Mohd Safri Ali, Rahimah \\ Embong, Hanif Md Lateh@Junid \\ Faculty of Islamic Contemporary Studies, Universiti Sultan Zainal Abidin, Malaysia
}

\author{
Wan Mohd Fazrul Azdi Wan Razali \\ Faculty of Leadership and Management, Universiti Sains Islam Malaysia
}

\begin{abstract}
Interfaith interaction is an important element of fostering harmony, tolerance and mutual respect between one to another religion. It needs to be nurtured and educated in the community, especially among youth at the university level. This is due to the fact that they are the ones who will inherit the country's leadership in the future. This study aims to look at the framework of interfaith interaction that can be embedded among the students in the Department of Usuluddin at the Faculty of Islamic Contemporary Studies (FKI), Sultan Zainal Abidin University (UniSZA). This study uses a document analysis method on two documents which are pro forma of comparative religion course and scholarly exercises written by students. This study found that comparative religion course contains values of interfaith interaction emphasized in the pro forma of this course especially in the third learning outcome (CLO3). This element is applied through one-course evaluation, which is a presentation assignment and two off-campus activities, which are a visit to the house of worship and scholarly writing training. Through these three activities, the framework for interfaith interaction can be developed among Muslim and non-Muslim students through the Comparative Religion course offered by the Department of Usuluddin, FKI, UniSZA.

Keywords: Educational Thought, Islamic Mathematics, KH. Fahmi Basya, Muslim Scholar, Holistic Education.
\end{abstract}

\section{Introduction}

The variety of ethnicities, cultures and identities in current modern society poses a lot of problems in establishing social interaction, tolerance and unity among the communities in 
modern countries around the world including Malaysia. Nurturing a harmonious atmosphere in a multi-ethnic society such as in Malaysia is not a simple accomplishment. For macro and micro factors such as political, economic, social, historical events, daily social interactions, culture, language and religion have greatly influenced individuals' attitudes and behaviors in daily life especially in interactions across ethnic boundaries (Tamring, 2008; Ramli, Talib, Hassan, \& Manaf, 2018).

In a pluralistic society, these myriad factors need to be respected as it can instill a tolerance embodiment in societal behaviors. These differences should also not be viewed skeptically or perceived as a reason for antagonistic attitudes between races and religions. Instead, they should even be the catalysts for strengthening the relationship among society. Most importantly, diversity and difference are not barriers for interaction between races and religions, but rather should be considered as a uniqueness and privilege in a country with a multi-racial and religious community (Awang, 2001; Baharuddin 2012; Abdullah \& Hamat, 2007; Abazeed, 2018).

Islam as an all-encompassing religion highly encourages interaction in the diversity of religions and nations. As explained by Allah S.W.T in Surah al-Hujurat (49:13) (Zain et al., 2018): "O mankind, indeed We have created you from male and female and made you peoples and tribes that you may know one another. Indeed, the most noble of you in the sight of Allah is the most righteous of you. Indeed, Allah is Knowing and Acquainted".

This verse clearly proves that human diversification is the basis of interaction and cooperation between races and religions. Therefore, Islam rejects elements that can lead to conflict between people (Halim \& Awang, 2016; Karimi \& Eshaghi, 2018). Although each religion has its differences, there are many similarities that can be shared by all members of society, especially in matters related to morals and ethics such as integrity, punctuality, trust, universal brotherhood and so on (Baharuddin, 2012). Therefore, the differences in society are not necessarily perpetual, since they can agree on other things that contain correlations.

\section{Methodology}

This study uses a document analysis method on two main documents. First, pro forma that is the basis of the teaching and learning process in Comparative Religion course. By reviewing the pro forma document, this study can identify the extent to which the integration between the values of interfaith interaction is to be achieved in CLO3 with the method of evaluating Comparative Religion course. The second document is 22 students' scholarly exercises written by undergraduates Bachelor of Usuluddin with Honors and Bachelor of Usuluddin and Counseling with Honors for the second semester of 2016/2017 and the second semester of 2017/2018 sessions. Through these scholarly exercises, this study is able to recognize the topics related to comparative religion and the values of interfaith interaction practiced by students in their research methodologies. In addition, this study also used the method of observation on the visits to the house of worship conducted by the Department of Usuluddin. Among the visits to the 
house of worship conducted includes the visit to the Buddhist Temple on October 25, 2010 in Tumpat, Kelantan, the visit to the Christian Church on April 26, 2016 in Penang and a visit to the Sikh Gurdwara on November 25, 2018 in Malacca. As a result of these visits, the process of interaction between the students and the particular religious followers visited was accomplished smoothly and achieving the expected goals of the Comparative Religion course.

\section{Interfaith Interaction in Malaysia}

In the Malaysian context, a diverse society is often tested with a variety of religious and racial issues that are seen to threaten the unity of religions and races. Islam and Muslims are often blamed for issues involving religions. However, Islam as a religion of rahmah has introduced various rules and universal values to ensure this harmony continues. Among them is Islam celebrates values such as independence, love, tolerance and brotherhood which is the human nature that Allah has given to all His creatures. With these universal values, people build relationships with each other despite the differences in religions, beliefs, languages, societies, cultures and ethnicities (Khambali \& Halid, 2008).

Among the religious and racial issues recorded in the history of the societal development in Malaysia are the events of Natrah in 1950, the issue on the usage of the word Allah in 2007 (Mas'od, 2008; Yaacob, 2010) on the issue of three churches being flung with petrol bombs (Utusan Malaysia, 9/1/2010), the case of the Selangor Islamic Religious Department (JAIS) on the raid at Muhibbah Dinner event at the Methodist Church in Damansara Utama (DUMC), Petaling Jaya (Malaysiakini, 4/8/2011). The latest issue is the issue of riots at the Sri Maha Mariamman Temple which was initially identified as an internal issue involving management, but due to religious provocation and racial sentiment related to the Hindu religious symbol which is the temple, has led to life-threatening riot (Harian, 27/11/2018).

Since these religious issues are interpreted differently based on their personal and social interests, they have led to dissension in society. In this regard, every member of the community should be sensitive to other religions because any speech or action that is seen as insulting to other religions can cause dissatisfaction in society (Zain et al., 2018). Therefore, an ongoing effort should be considered to ensure that a united nation in Malaysia can be established in society. This effort should be carried out proactively with the cooperation of all the authorities and the people of various nations to maintain and strengthen the unity of the nation in Malaysia. However, this is not an easy task to be accomplished because there are obstacles and challenges that need to initially be overcome (Khadijah \& Halid, 2008; Halim \& Awang, 2016).

In this regard, religious tolerance is the best approach. Many models of religious tolerance can be extracted from the writings of Islamic scholars such as al-Shahrastani in the book of alMilal wa al-Nihal, Alhazen through the book of al-Fasl fi al-Milal wa al-Ahwa 'wa al-Nihal, Ibnqayyim in Hidayah al-Hayara fi Ajwibah al-Yahud wa al-Nasara and so on. However, in order to develop an attitude of religious tolerance, values of interaction need to be worked out first in society. This pure effort can be facilitated through the education system which is a form of social interaction between humans. The social aspects of the educational process can be conceptualized by looking at the interdependence of students with other students in the learning 
process. In other words, educational institutions are a great place for children to get to know themselves and the community around them. In Malaysia, there is a National Education System and one of the overall goals is national unity (Yusof, 2005; Tamring, 2008; Kumar, 2017). Therefore, students at higher levels, especially in public universities should be given the opportunity to realize national unity. Among the efforts that can be executed is to offer courses that enable students to interact with each other despite their religious and cultural differences through the process of teaching and learning in the field of comparative religion (Razali et al. 2015; Zain et al., 2018).

\section{Comparative Religion Course at the Department of Usuluddin, FKI}

In general, Faculty of Islamic Contemporary Studies (FKI) offers Comparative Religion course at two centers of study: Department of Usuluddin and Centre for Education, Da'wah and Islamic Civilization (PDPI). However, this article will focus on Comparative Religion course offered by the Department of Usuluddin to three programs which are Bachelor Degree of Usuluddin with Honors (USI 31303), Bachelor Degree of Usuluddin and Counseling with Honors (USI 31303) and Diploma in Islamic Studies (Usuluddin) (USD 21303). This is due to the fact that the number of students in the Department of Usuluddin who take this course is greater than the students in the Centre for Education, Dakwah and Islamic Civilization (PDPI).

Before discussing the Comparative Religion course any further, the summary of pro forma information regarding the course is as follows (Zain et al., 2018): 
INTERNATIONAL JOURNAL OF ACADEMIC RESEARCH IN BUSINESS AND SOCIAL SCIENCES Vol. 9, No. 11, November, 2019, E-ISSN: 2222-6990 @ 2019 HRMARS

\begin{tabular}{|c|c|c|c|c|}
\hline Programme & CLO & $\begin{array}{c}\text { Bloom's } \\
\text { Taxonomy }\end{array}$ & Evaluation & $\%$ \\
\hline $\begin{array}{c}\text { Diploma } \\
\text { (USD21303) }\end{array}$ & \multirow{2}{*}{$\begin{array}{l}\text { CLO1). Discussing the } \\
\text { concepts of abrahamic } \\
\text { religions and natural } \\
\text { religions and its } \\
\text { importance in the } \\
\text { field of comparative } \\
\text { religion. }\end{array}$} & $\mathrm{C} 2$ & Quiz & $\begin{array}{l}4 \\
0\end{array}$ \\
\hline $\begin{array}{l}\text { BD Usuluddin } \\
\text { /BD Usuluddin } \\
\text { and Counseling }\end{array}$ & & C3 & Test & $\begin{array}{l}2 \\
0\end{array}$ \\
\hline $\begin{array}{c}\text { Diploma } \\
\text { (USD21303) }\end{array}$ & \multirow{2}{*}{$\begin{array}{l}\text { CLO2) Comparing the } \\
\text { main aspects of world } \\
\text { religions with Islam. }\end{array}$} & A3 & $\begin{array}{c}\text { Final } \\
\text { Examination }\end{array}$ & $\begin{array}{l}4 \\
0\end{array}$ \\
\hline $\begin{array}{l}\text { BD Usuluddin } \\
\text { /BD Usuluddin } \\
\text { and Counseling }\end{array}$ & & $\mathrm{C} 5$ & $\begin{array}{c}\text { Final } \\
\text { Examination }\end{array}$ & $\begin{array}{l}5 \\
0\end{array}$ \\
\hline $\begin{array}{c}\text { Diploma } \\
\text { (USD21303) }\end{array}$ & \multirow[t]{2}{*}{$\begin{array}{l}\text { CLO3) Explaining the } \\
\text { views of Islam on } \\
\text { religions other than } \\
\text { Islam. }\end{array}$} & C4 & $\begin{array}{c}\text { Assignment } \\
\& \\
\text { Presentatio } \\
\mathrm{n} \\
\end{array}$ & $\begin{array}{l}2 \\
0\end{array}$ \\
\hline $\begin{array}{l}\text { BD Usuluddin } \\
\text { /BD Usuluddin } \\
\text { and Counseling }\end{array}$ & & C6 & $\begin{array}{c}\text { Assignment } \\
\& \\
\text { Presentatio } \\
\mathrm{n}\end{array}$ & $\begin{array}{l}3 \\
0\end{array}$ \\
\hline
\end{tabular}

Table 1: Proforma for Comparative Religion Course

Based on Table 1 above, there are two key items in the pro forma course that need to be discussed to see how effective the values of interfaith interaction can be achieved and then build the interaction framework through the Comparative Religion course at the Department of Usuluddin.

The first item is a learning outcome (CLO) which is a competency that students want to achieve and can be measured as a result of learning activities. Learning activities include an entire study, course or program of study. When students complete a learning activity, they will usually acquire something that they did not have before, such as new knowledge, awareness, understanding, skills and competencies. By defining learning outcomes from the beginning, students will have a clear picture of the standards that should be achieved upon completion of their learning activities (Standard Program Pengajian Islam, 2014). Therefore, the results of the study designed for the Comparative Religion course offered by the Department of Usuluddin should also reach the expected target. In order to achieve learning outcomes, the assessment applied in the course must also be in line with the learning outcomes set. 
Based on the results of the study (CLO1, CLO2 \& CLO3) in the pro forma for Comparative Religion course, it was found that all three CLOs are the same CLOs used in Diploma and Bachelor Degree. What distinguishes the two is the aspect of Bloom's Taxonomy and the weight or percentage. All Bloom's Taxonomies in all three of these CLOs are more than cognitive domains except in CLO2 at the diploma level which is affective in nature.

The second item is from the assessment aspect used to achieve the specified learning outcomes. According to the Kerangka Kelayakan Malaysia (2013), assessment is a process of finding evidence that a student who has successfully completed a course or graduated from a program offered by a Higher Education Facility has achieved a specified level of performance or competence. Whereas in the Standard Program Pengajian Islam (2014), student evaluation is a very important aspect of quality assurance as it can demonstrate the achievement of learning outcomes. The results of this evaluation are also the basis for the award of qualifications. Therefore, students' assessment methods need to be clear, consistent, effective, reliable and in line with current practices and must clearly contribute to the achievement of learning outcomes (Zain et al., 2018).

In the Comparative Religion course at the Department of Usuluddin, the evaluation aspect is generally divided into three forms of assessment: quizzes (tests), final exams and projects (assignments and presentations). For CLOs whose Bloom Taxonomy is cognitive and affective, the forms of evaluation used are quizzes (tests) and final exams. This form of evaluation can be seen in CLO1 and CLO2 representing $70 \%$ to $80 \%$ of the score. The other $20 \%$ to $30 \%$ are evaluated in $\mathrm{CLO} 3$ through assignments and presentations. Higher percentages of assessments in the form of tests and exams than percentages in assignments and presentations indicate that students are more likely to study information than to apply the values of interfaith interaction in their lives. Therefore, this article focuses on the aspects of assessment in CLO3 as assignments and presentations as well as other supporting activities to see how interfaith interaction elements can be achieved in learning this course (Zain et al., 2018).

\section{The Values of Interfaith Interaction in Comparative Religion Course}

The values of interfaith interaction in this course can be seen in the CLO3 learning outcomes which account for $20 \%$ to $30 \%$ of the overall course evaluation. This is because, in this CLO3, the result of learning is that students can express their views on other religions. Therefore, in order to articulate the Islamic view, students must first know the important aspects of a religion. This information can be obtained through the process of interaction and dialogue with other religions, as well as from other sources. Indirectly, it will generate respect and could apply the values of religious unity among the diverse society in Malaysia (Zain et al., 2018).

Although the lecture room is a place for students to study Comparative Religion course, it is not a particular place that can help Muslim students to interact with non-Muslim students. This is due to the fact that the course is offered only to Muslim students. Therefore, the lack of interaction values in this Comparative Religion course needs to be supported with evaluation and other activities. In the Department of Usuluddin, there are three approaches used. First, the evaluation of $\mathrm{CLO} 3$ is applied in the form of assignments and presentations. This approach 
enables students to interview and interact with non-Muslim students to obtain data and information on other religions from the right sources.

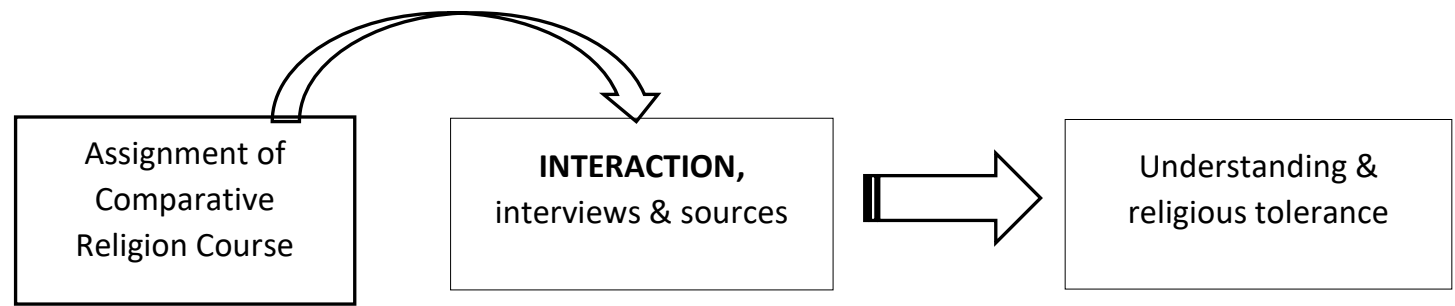

Figure 1: The Values of Interaction in Assignments and Presentations

The second is a student's visit to the different house of worship in Malaysia. The program is implemented in each semester offered by the course and is included in the course pro forma as one of the syllabuses for the course. During the visit, students will have the opportunity to interact with other religious leaders and followers, listen to briefings, taking pictures and have a closer look at the house of worship of other religions (Zain et al., 2018). In this case, two possibilities will occur. First, students are likely to get a clear picture of important aspects of religion, while adding to the information they find in the lecture halls. Secondly, the information may be different from the theory and knowledge learned in the classroom. In this situation, students will obtain clear and accurate information from those religious sources through interactions and interviews with religious leaders, which may prevent them from having misunderstandings about a religion studied in the classroom or information obtained through reading comparative religion textbooks.

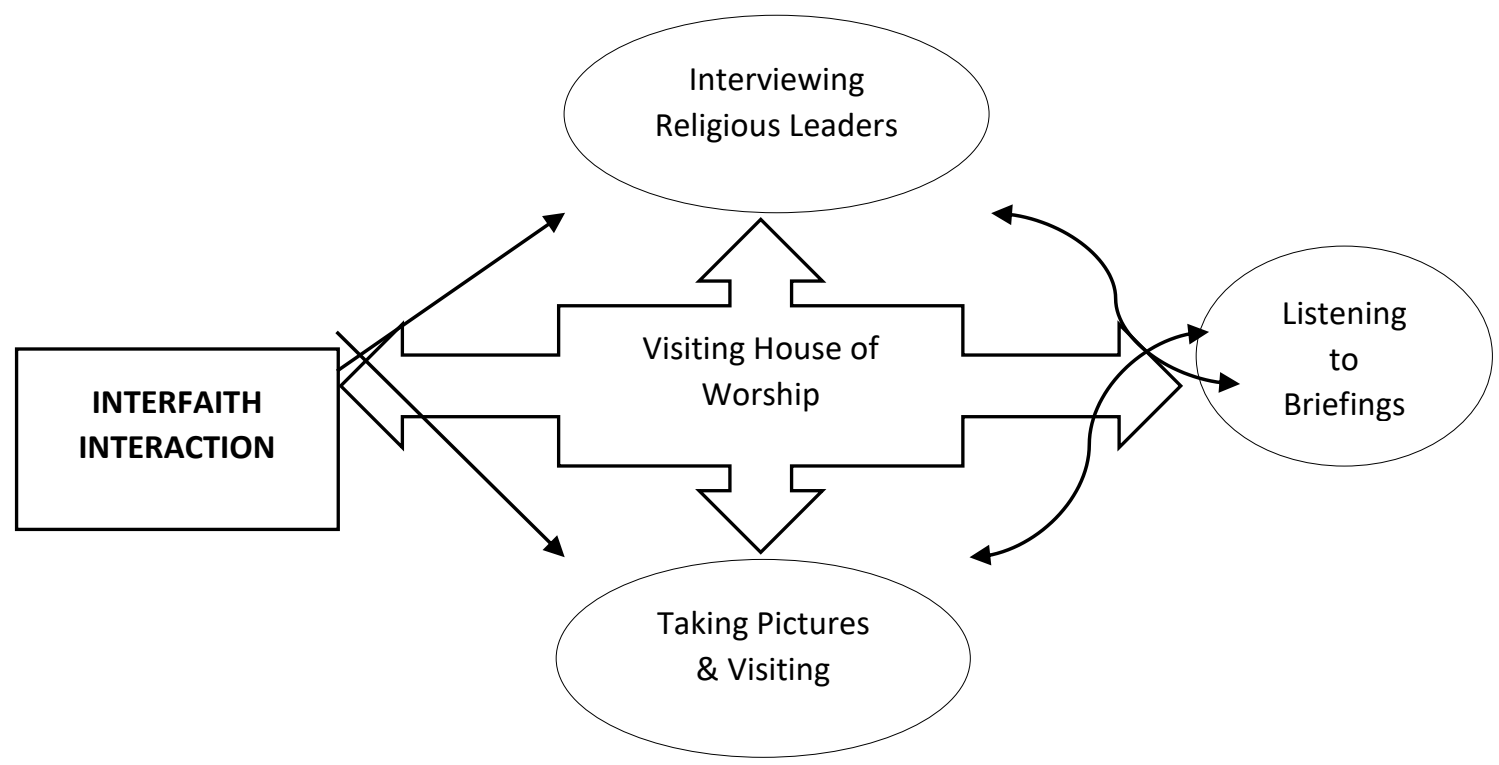

Figure 2: The Values of Interaction in the Visits to House of Worship 
The third activity is a separate activity from the original course but it helps students to interact with different religions. The activity is a scholarly writing exercise that provides opportunities for students to research and analyze specific issues within a religion. In the scholarly writing exercises, students will obtain data either through interviews and questionnaires to find out what non-Muslim students think about religion (Zain et al., 2018). Through these two methods, there is an indirect interaction between Muslim and non-Muslim students. In this regard, the framework of interaction values in the scholarly writing exercise is similar to the interaction framework found in the course presentation tasks as shown in figure 1 above.

Examples of completed scholarly writings (IRF 4043) in the Bachelor Degree semester 2, 2016/2017:

1) Interaksi Sosial Antara Masyarakat Islam dan Buddha di Kelantan.

2) Konsep Syurga dan Neraka Menurut Islam dan Hindu.

3) The Concept of Prophet in Islam and Judaism: A Comparative Study.

4) Kebebasan Beragama: Kajian Perbandingan di Antara Islam Dengan Kristian.

5) Kefahaman Terhadap Konsep Manusia Pertama: Kajian Perbandingan Antara Pelajar Islam dan Non-Muslim Di UniSZA.

6) Persepsi Orang Bukan Islam Terhadap Solat Dalam Islam: Kajian Terhadap Pelajar Bukan Islam UniSZA.

7) Persepsi Pelajar Bukan Islam Di UniSZA Terhadap Kitab Suci Al-Quran.

8) Persepsi Konsep Kenabian Rasulullah S.A.W Dalam Kalangan Non-Muslim di UniSZA.

9) Konsep Malaikat Dan Angel: Satu Kajian Perbandingan Menurut Agama Islam dan Kristian. 10) Konsep Dosa Warisan Dalam Agama Kristian dari Perspektif Agama Islam.

11) Metodologi Mujadalah Dengan Golongan Bukan Islam Menurut Dr. Zakir Naik.

12) Hak Asasi Manusia: Kajian Perbandingan Menurut Islam dan Perspektif Barat.

13) Unsur-Unsur Ketuhanan di Dalam Filem God of Egypt: Kajian Menurut Pandangan Islam.

Among the example of scholarly writings (IRF 4043) that have been completed in the Bachelor Degree semester 2, 2017/2018:

1) Perbandingan Konsep Ketuhanan Menurut Islam dan Zoroaster.

2) Ketuhanan Antara Islam Dan Kristian Menurut Sheikh Ahmad Deedat.

3) Konsep Ketuhanan Menurut Ahli Falsafah Islam dan Barat.

4) Hak Asasi Manusia Menurut Perspektif Agama Islam dan Buddha.

5) Isu dan Kefahaman Dalam Kalangan Pelajar UniSZA Bukan Islam Terhadap Kalimah Allah Dalam Bible.

6) Konsep Jihad Dalam Islam dan Perang Salib Dalam Kristian.

7) Konsep Uluhiyyat: Suatu Kajian Perbandingan Antara Islam dan Yahudi.

8) Nabi Isa As: Perbezaan Kalimatullah Dalam Islam dan Teologi Kristian. 
9) The Concept of Divinity in Christianity and Hinduism: A Comparative Study.

Overall, the Comparative Religion course offered by the Department of Usuluddin can create a framework for interfaith interaction through assessments and activities that are in line with the learning outcomes outlined in the pro forma of the course. The framework is expected to form one of the most important goals to be achieved in the pluralistic society in Malaysia, which are national unity and religious tolerance in society.

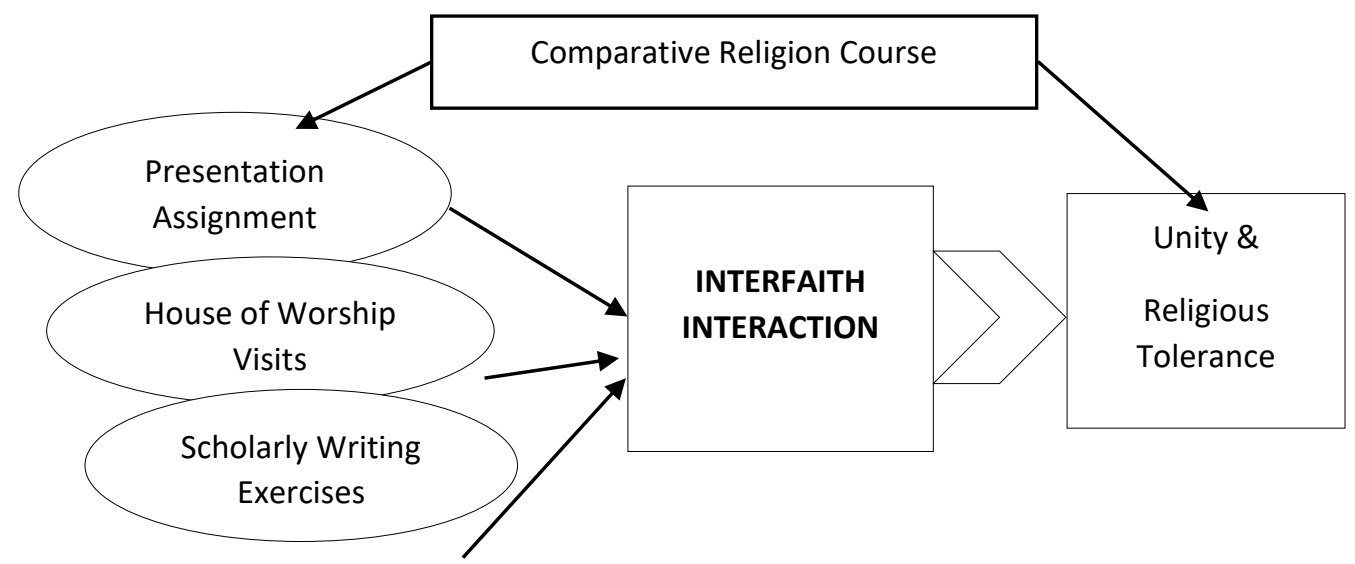

Figure 3: Framework of Interfaith Interaction in Comparative Religion Course

\section{Conclusion}

Comparative Religion course at the Department of Usuluddin, Faculty of Islamic Contemporary Studies emphasized the elements of interaction, dialogue, sharing common values and getting to know one another. It is emphasized in the syllabus of the course through students' assignments and presentations on Islamic views of other religion conducted in academic demeanor. To further enhance students' understanding of other religions, the students were exposed to two activities outside of the lecture hall, which are the visits to other houses of worship and scholarly writing exercise. Both of these activities provide an opportunity for students to interact more closely with other religions through interviews, dialogues and questionnaires. Information from the original sources obtained through this method will be of added value to students in understanding the key aspects of a religion. Thus, interfaith interactions play an important role in nurturing unity in a country with multi-racial and multireligion as Malaysia. Unity formed through the values of interfaith interaction will reinforce the spirit of religious tolerance as every member of the community has an understanding of other religions based on the right sources. 
INTERNATIONAL JOURNAL OF ACADEMIC RESEARCH IN BUSINESS AND SOCIAL SCIENCES

Vol. 9, No. 11, November, 2019, E-ISSN: 2222-6990 @ 2019 HRMARS

\section{Corresponding Author}

Rahimah Embong, Ph.D, is Associate Professor at Department of Education, Dakwah \& Islamic Civilization, Faculty of Islamic Contemporary Studies, Universiti Sultan Zainal Abidin (UniSZA), Kampus Gong Badak, 21300 Kuala Nerus. Terengganu, Malaysia.

Email: rahimahembong@unisza.edu.my

Funding: This study is a part of research findings with Fundamental Research Grant Scheme (FRGS), FRGS/1/2018/SSI03/UNISZA/02/3, and project code RR269 and was supported and financed by the Ministry of Higher Education (MoHE) and Sultan Zainal Abidin University (UniSZA).

Competing Interests: The authors declare that they have no competing interests.

Contributors/Acknowledgement: All authors contributed equally to the conception and design of the study.

\section{References}

Abazeed, R. A. M. (2018). The Impact of Talent Management on Organizational Commitment of the employees of telecommunication companies in Jordan: The Mediating Role of Employee Work Engagement, International Journal of Academic Research in Accounting, Finance and Management Sciences 8 (4): 153-162.

Abdullah, W. S. W \& Hamat, M. F. (2007). Konsep Asas Islam dan Hubungan Antara Agama. Jabatan Akidah dan Pemikiran Islam, Akademi Pengajian Islam, Universiti Malaya.

Awang, J. (2001). "Perpaduan dan Komposisi Masyarakat dari Perspektif Ibn Khaldun". Jurnal Usuluddin 14: 23-32.

Baharuddin, S. A. (2012). Modul Hubungan Etnik, Kementerian Pengajian Tinggi Malaysia. Skudai: Penerbit UTM Press.

Halim, M. N. A., \& Awang, J. (2016). Tahap Persepsi Muslim Dan Non-Muslim Mengenai Hubungan Interaksi Antara Agama: Kajian Tinjauan Di Negeri Kedah Dan Selangor. Journal of Social Sciences and Humanities. E-Bangi 11 (2): 104-124.

Karimi, O. \& Eshaghi, R. (2018). The Impact of Cultural Intelligence on Competitive Intelligence. Multilingual Academic Journal of Education and Social Sciences, 6(1), 199-213.

Kerangka Kelayakan Malaysia, http://www2.mqa.gov.my/QAD/bm/types5.cfm, 19 Januari 2019. Khambali, K. M., \& Haled, M. H. M. (2008). "Toleransi Beragama dan Amalannya di Malaysia: Rujukan Kepada Artikel 11 Perlembagaan Persekutuan Malaysia". Jurnal Usuluddin 27, 8192.

Kumar, S. N. V. (2017). "Implikasi Budaya dan Agama ke atas Interaksi Antara Etnik dalam Kalangan Murid Sekolah di Malaysia". Journal of Social Sciences and Humanities.e-Bangi 12( 2): 272-286.

Malaysiakini, 7/11/2011, https://www.malaysiakini.com/letters/177975. 
Mas'od, M. A. (2008). "Hujah Menolak Penggunaan Kalimah 'Allah' oleh Kristian", Jurnal Penyelidikan Islam, Jabatan Kemajuan Islam Malaysia, Bil. 21, Kuala Lumpur: Percetakan Nasional Malaysia Berhad.

Ramli, N. F., Talib, O., Hassan, S. A., \& Manaf, U. K. A. (2018). Rasch Analysis and Differential Item Functioning of STEM Teachers' Instructional Preparedness Instrument for Urban and Rural Teachers. International Journal of Academic Research in Progressive Education and Development, 7(4), 211-222.

Razali, W. M. F. A. W. (2015). Kepentingan Ilmu Perbandingan Agama dalam Modul Pengurusan Mualaf di Negeri Sembilan: Analisis Perspektif Da'i dan Mad'u. Jurnal Pengurusan dan Penyelidikan Fatwa. 6: 65-85.

Standard Program Pengajian Islam. (2014). Petaling Jaya: Agensi Kelayakan Malaysia

Tamring, B. A. M. (2008). Pengaruh Agama Dalam Interaksi Dan Toleransi Etnik: Kajian Kes Ke Atas Pelajar Bumiputera Sabah Di Universiti Malaysia Sabah. Sekolah Sains Sosial. Universiti Malaysia Sabah.

Utusan Malaysia, 9/1/2010, https://www.utusan.com.my/berita/nasional/bakar-gereja-tidakboleh-dimaaf-1.230023.

Yaacob, F. (2010). Natrah (1937-2009), Cinta, Rusuhan, Airmata, Skudai: Penerbit Universiti Teknologi Malaysia.

Yusof, N. M. (2005). Pola Interaksi Sosial Dalam Kalangan Murid Pelbagai Etnik di Sekolah Menengah Kebangsaan Sekitar Sungai Petani, Kedah, Tesis Doktor Falsafah. Universiti Sains Malaysia.

Zain, A. D. M., Ali, M. S., Omar, S. H. S., \& Khairuldin, W. M. K. F. W. (2018). "The Role of Comparative Religion Course in UniSZA in Forming Interreligion Dialogue among Students". International Journal of Civil Engineering and Technology. 9(13):186-193. 